\title{
ERK Inhibitor GDC-0994
}

National Cancer Institute

\section{Source}

National Cancer Institute. ERK Inhibitor GDC-0994. NCI Thesaurus. Code C107241.

An orally available inhibitor of extracellular signal-regulated kinase (ERK), with potential antineoplastic activity. Upon oral administration, GDC-0994 inhibits both ERK phosphorylation and activation of ERK-mediated signal transduction pathways. This prevents ERK-dependent tumor cell proliferation and survival. The mitogen-activated protein kinase (MAPK)/ERK pathway is upregulated in a variety of tumor cell types and plays a key role in tumor cell proliferation, differentiation and survival. 